$\mathrm{A} \mathrm{J}_{\mathrm{sins}} \mathrm{H}$

Article history :

Received : 25.08.2014

Revised : 05.05.2015

Accepted : 29.05.2015

Members of the Research Forum

Associated Authors:

${ }^{1}$ Department of Agricultural

Economics, Dr. B.S. Konkan Krishi

Vidyapeeth, Dapoli, RATNAGIRI

(M.S.) INDIA

Author for correspondence : R.B. GODAMBE

Department of Agricultural

Economics, Dr. B.S. Konkan Krishi

Vidyapeeth, Dapoli, RATNAGIRI

(M.S.) INDIA
THEASIAN JOURNALOF HORTICULTURE

Volume 10 | Issue 1 | June, 2015 | 153-157

Visit us -www.researchjournal.co.in

\title{
Resource use efficiencies of okra in Thane district of Maharashtra
}

\section{R.B. GODAMBE，S.R. TORANE ${ }^{1}$ ，P.J. KSHIRSAGAR ${ }^{1}$ AND J.M. TALATHI ${ }^{1}$}

ABSTRACT : The functional relationship between inputs factors in production of okra namely independent variables like seed $\left(\mathrm{X}_{1}\right)$, fertilizers $\left(\mathrm{X}_{2}\right)$, plant protection $\left(\mathrm{X}_{3}\right)$, human labour $\left(\mathrm{X}_{4}\right)$ and dependent variable as okra production (yield) was estimated by Cobb-Douglas type production function. The co-efficient of determination $\left(\mathrm{R}^{2}\right)$ was 0.824 indicating that 82 per cent of the variation in the yield is explained by independent factor such as seed $\left(X_{1}\right)$, fertilizers $\left(X_{2}\right)$, plant protection $\left(\mathrm{X}_{3}\right)$ and human labour $\left(\mathrm{X}_{4}\right) \cdot \mathrm{R}^{2}$ was found to bestatistically significant. The functional analysis indicated that seed, fertilizer plant protection and human labour were used excessively. They need proper monitoring to increase allocative efficiency.

KEY WORDS : Inputs, Production, Production function, Resource use efficiency

HOW TO CITE THIS ARTICLE : Godambe, R.B., Torane, S.R., Kshirsagar, P.J. and Talathi, J.M. (2015). Resource use efficiencies of okra in Thane district of MaharashtraThane. Asian J. Hort., 10(1) : 153-157. 